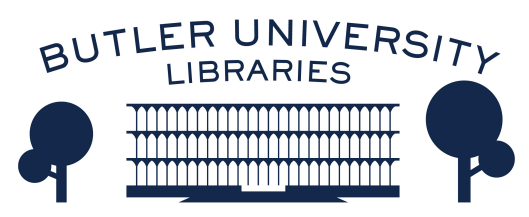

Journal of Hindu-Christian Studies

Volume 25

Article 4

November 2012

\title{
The Malleability of Yoga: A Response to Christian and Hindu Opponents of the Popularization of Yoga
}

Andrea R. Jain

Follow this and additional works at: https://digitalcommons.butler.edu/jhcs

Part of the Religion Commons

\section{Recommended Citation}

Jain, Andrea R. (2012) "The Malleability of Yoga: A Response to Christian and Hindu Opponents of the Popularization of Yoga," Journal of Hindu-Christian Studies: Vol. 25, Article 4.

Available at: https://doi.org/10.7825/2164-6279.1510

The Journal of Hindu-Christian Studies is a publication of the Society for Hindu-Christian Studies. The digital version is made available by Digital Commons @ Butler University. For questions about the Journal or the Society, please contact cbauman@butler.edu. For more information about Digital Commons @ Butler University, please contact digitalscholarship@butler.edu. 


\title{
The Malleability of Yoga: A Response to Christian and Hindu Opponents of the Popularization of Yoga
}

\author{
Andrea R. Jain \\ Indiana University-Purdue University Indianapolis
}

FOR over three thousand years, people have attached divergent meanings and functions to yoga. Its history has been characterized by moments of continuity, but also by divergence and change. This applies as much to precolonial yoga systems as to modern ones. All of this evidences yoga's malleability (literally, the capacity to be bent into new shapes without breaking) in the hands of human beings. ${ }^{1}$

Yet, today, a movement that assumes a vision of yoga as a static, homogenous system rapidly gains momentum. That movement opposes the contemporary popularization of yoga, maintaining that people have been fooled into thinking that yoga is simply a fitness product for enhancing well-being. Opponents target the most widely embraced forms of modern yoga today, those of postural yoga, which involve sequences of asana or postures that are, through pranayama or "breathing exercises," synchronized with the breath. ${ }^{2}$ The movement warns that, although today millions embrace postural yoga as a physical fitness routine, yoga is in fact religious, and, more specifically, it is definitively Hindu.

There are both Hindu and Christian participants in the movement against the popularization of yoga. Though Hindu and Christian oppositions are not entirely the same, at their core, they share the assumption that yoga is Hindu. This assumption reflects an understanding of yoga as a homogenous system that remains unchanged by its shifting spatial and temporal contexts. It also depends on notions of Hindu authenticity, origins, and even ownership. Both Hindu and Christian opponents add that the majority of contemporary yogis fail to recognize that yoga is Hindu. ${ }^{3}$

Suspicious of decontextualized understandings of yoga and, consequently, the Hindu and Christian oppositional movements they support, this article uncovers the contextsensitivity of yoga by selecting from the vast array of yoga traditions. Based on that assessment, I suggest that the history of yoga evidences the absence of any unchanging essence to the function or meaning of yoga. Instead, it is a history of deconstruction and reconstruction. In other words, the history of yoga suggests that the meanings and functions of yoga are malleable, thus a decontextualized definition of yoga cannot stand serious historical scrutiny.

Opponents of the Popularization of Yoga

Christian opponents of the popularization of yoga maintain that Christians should not

Andrea R. Jain is Assistant Professor of Religious Studies at Indiana University-Purdue University Indianapolis. Her research interests include theories of religion as well as religion in relation to the body. More specifically, her research focuses on the transnational construction and global popularization of modern yoga. Andrea's current projects include studies on the intersections of consumer culture and modern yoga as well as modern yoga gurus. She recently authored an article entitled "The Dual-Ideal of the Ascetic and Healthy Body: The Jain Terapanth and Modern Yoga in the Context of Late Capitalism," which was published in Nova Religio. 
embrace yoga, which is Hindu and is consequently in conflict with Christian doctrine and an obstacle on the path to salvation. ${ }^{4}$

In 2010, Albert Mohler, renowned evangelical leader and president of the Southern Baptist Theological Seminary, became the most vocal representative of this position when he publicly warned Christians about "the contradictions between their Christian commitments and yoga. ${ }^{5}$ Mohler added:

The story of yoga [in America] is a twisted tale of how something that is so essentially rooted in Hinduism could become part of American popular culture and increasingly a part of the lives of many who would identify themselves as Christians - it's a large number of persons. ${ }^{6}$

Other contemporary evangelical Christian leaders who oppose the popularization of yoga include: Pat Robertson, television evangelist and founder of the Christian Coalition of America; John MacArthur, pastor of the Grace Community megachurch in Sun Valley, California; and Mark Driscoll, pastor of the Mars Hill megachurch in Seattle, Washington. Their positions range from describing yoga as self-destructive to associating it with Satan. For example, in a 2010 discussion in front of a live audience, Driscoll made the following statement about yoga:

Yoga is demonic... It's absolute paganism... Yoga and meditation and Easternism is [sic] all opening to demonism... if you just sign up for a little yoga class, you're signing up for a little demon class. That's what you're doing. And Satan doesn't care if you stretch as long as you go to hell. ${ }^{7}$

Christian opposition is not limited to these Protestant evangelicals. The Roman Catholic Church officially warned against yoga in 1989 when the Congregation for the Doctrine of the Faith (CDF), responsible for overseeing Church doctrine, submitted the "Letter to the Bishops of the Catholic Church on Some Aspects of Christian Meditation," authored by Cardinal Joseph Ratzinger (b. 1927; elected to the papacy as Pope Benedict XVI in 2005) and approved for publication by Pope John Paul II (1920-2005). ${ }^{8}$ The CDF strives to prevent Catholics from undermining Church doctrine when they embrace ideas or practices that the church deems non-Christian. The letter, however, goes beyond concern with doctrinal compatibility and deems "eastern" body practices a threat to human stability. Although the letter does not name yoga explicitly, it is implicitly the object of attack, since contemporary Christians embrace it far more often than any other eastern body practice. The letter suggests that "psychophysical symbolism" can become an "idol and thus an obstacle" to experiencing God and states that body practices "can degenerate into a cult of the body." In fact, the consequences of the bodily experiences that result from such practices can include "mental schizophrenia," "psychic disturbance," or "moral deviations."10

Hindu opponents of the popularization of yoga maintain that postural yoga is the product of a profit-driven market featuring the cooptation and corruption of an otherwise authentic, Hindu system. They are similar to Christian opponents of the popularization of yoga insofar as they argue that yoga is definitively Hindu, though popularized forms dramatically ignore or dilute its Hindu identity. The two positions also differ. On the one hand, Christian opponents doubt yoga's proclaimed merits and warn Christians against its embrace. On the other hand, Hindu opponents valorize what is perceived as a correct form of yoga by reifying its associations with what they identify as authentic Hinduism and denouncing popularized varieties as inauthentic. In short, Hindu opponents are concerned that popularized forms of yoga are corruptions of the single authentic yoga, and they do not think most contemporary yogis give Hinduism due credit for being the historical source of yoga.

Hindu opponents argue that the frequent failure to acknowledge yoga's Hindu origins is a self-conscious marketing strategy that is the consequence of problematic stereotypes about Hinduism. A statement by the Hindu American Foundation (HAF), for example, refers to the stereotype of Hinduism as nothing but "caste, 
cows and curry." ${ }^{11}$ Aseem Shukla and Sheetal Shah argue that marketers emphasize yoga's benefits for mental and physical health without mention of Hinduism in order to maximize profit." Ramesh Rao suggests that "savvy marketers" avoid defining yoga as Hindu in order to appease Christians who want to practice yoga and "hang on to Jesus." 13

Though concerns about problematic stereotypes are understandable, Hindu opponents respond to them with yet another problematic, simplistic vision of yoga. Some go beyond arguing for yoga's Hindu origins and suggest that yoga is the property of Hinduism. In such accounts, the yoga market represents the "theft of yoga."14 Shukla, for example, argues:

[Yoga is] a victim of overt intellectual property theft, absence of trademark protections and the facile complicity of generations of Hindu yogis, gurus, swamis and others that offered up a religion's spiritual wealth at the altar of crass commercialism. $^{15}$

Hindu opponents also argue that authentic yoga is corrupted when yoga undergoes popularization. They prescribe yoga, not only as postural yoga, but also as a Hindu path toward the experience of deep, spiritual realizations. For example, the HAF approves of yoga as a means of health, "But the Foundation argues that the full potential of the physiological, intellectual and spiritual benefits of asana would be increased manifold if practiced as a component of the holistic practice of Yoga." ${ }^{16}$ That "holistic practice" is equated with the system prescribed in the ancient Indian text, the Yoga Sutra of Patanjali. ${ }^{17}$ The HAF adds:

Yoga, as an integral part of Hindu philosophy, is not simply physical exercise in the form of various asanas and pranayama, but is in fact a Hindu way of life. The ubiquitous use of the word 'Yoga' to describe what in fact is simply an asana exercise is not only misleading, but has lead to and is fueling a problematic delinking of Yoga and Hinduism... ${ }^{18}$
Hindu opponents maintain that, although yoga is Hindu, anyone can embrace it, but, according to Shukla, they should be warned that yoga is definitively Hindu and will make Hindu anyone who embraces it:

But be forewarned. Yogis say that the dedicated practice of yoga will subdue the restless mind, lessen one's cravings for the mundane material world and put one on the path of self-realization - that each individual is a spark of the Divine. Expect conflicts if you are sold on the exclusivist claims of Abrahamic faiths - that their God awaits the arrival of only His chosen few at heaven's gate - since yoga shows its own path to spiritual enlightenment to all seekers regardless of affiliation. ${ }^{19}$

Given such warnings, it is not surprising that Mohler finds allies in Hindu opponents of the popularization of yoga. ${ }^{20}$

\section{Pre-Colonial Yoga Systems}

The definition of yoga as Hindu is premised on the idea that a pre-colonial Hindu ur-system or ur-text from which subsequent yoga systems draw exists. Yet such a system or text does not exist, rather pre-colonial yoga systems are characterized by dramatic variation. For this reason, Geoffrey Samuel provides pre-colonial yoga with the following wide-reaching definition: "disciplined and systematic techniques for the training and control of the human mind-body complex, which are also understood as techniques for the reshaping of human consciousness towards some kind of higher goal." 21

The history of yoga evidences that its aims are specific to particular contexts. Even before yoga connoted "disciplined and systematic techniques," the term yoga (from the Sanskrit root yuj, meaning "to bind" or "to yoke") appeared in Indian literature beginning with its earliest known text, the Rig Veda Samhita (c. fifteenth century BCE), and referred to the yoke used to bind an animal to a plow or chariot and also to an entire war chariot. A wartime connotation of yoga was prevalent in ancient India. In the Mahabharata, heroic warriors 
about to die are described as yoga-yukta, "yoked to yoga," the yoga or chariot believed to deliver them to heaven. ${ }^{22}$

In a strikingly different application of the term, the Bhagavad Gita, a dialogue in the Mahabharata between the warrior, Arjuna, and his charioteer, Krishna, prescribes yoga as a multivalent path to liberation from the cycle of rebirth. That path requires detachment from the fruits of actions, theistic devotion to Krishna, and the cultivation of mystical knowledge.

And what about Patanjala yoga as expounded in the Yoga Sutra of Patanjali (c. fourth to fifth century (E), famously identified as the "classical" text on yoga? The author propounds an eightfold ascetic discipline grounded in a dualist philosophy, Samkhya, which emphasizes meditation as a means of refining consciousness, a process that leads up to liberation from embodied existence. The aim is to still the mind in order to realize the true nature of the self as radically distinct from the body, the ego, and the rest of the material world, thus ensuring the self's progress toward liberation.

Thought the Rig Veda Samhita, the Mahabharata, and the Yoga Sutra are traditionally identified as Hindu, the history of yoga is also characterized by religious variation and interreligious exchange. According to Samuel:

[I]t is important to take 'yoga' in a wide sense, and to include the variety of related Buddhist and Jain practices, which may or may nor (sic) be called yoga, as well as the yogic and tantric traditions within the various religious currents that eventually led to modern Hinduism. . . developments within these various traditions were closely entwined with each other." 23

Examples of interreligious exchange include those between the Patanjala Yoga of the Yoga Sutra (fourth to fifth century CE), the Mahayana Buddhist Yogacara school (third to fourth century (E), and the Jain thinker, Haribhadra (eighth CE). ${ }^{24}$ Like Patanjala yoga, Yogacara prescribed an eightfold discipline that emphasized meditation as the means of liberation from suffering existence. In Yogadrishtisamuccaya, Haribhadra synthesized a systematic yoga discipline, based on both the Yoga Sutra and Jain doctrine.

In the tenth to eleventh centuries, hatha yoga ("yoga of forceful exertion") emerged as yet another yoga system. This system of yoga included a view of the body as a microcosm of the universe and emphasized the practitioner's ability to channel subtle energy within the body. As a component of tantra, hatha yoga was based on a non-dualist philosophy, and practitioners sought to increasingly refine consciousness, not as a means of liberation from embodied existence, but as a means of achieving a state of divine consciousness while remaining in embodied existence. ${ }^{25}$ Participants in the Nath yoga tradition were the earliest systematizers of hatha yoga and emphasized bodily immortality, sexual pleasure, as well as supernatural and sociopolitical powers as yoga's aims. ${ }^{26}$ Such benefits were associated with yoga prior to the Nath Yogis, but they were the first to identify these benefits as the explicit aim of the yogi. ${ }^{27}$ Sometimes these aims were nefarious, and thus Nath Yogis had reputations as sinister villains. ${ }^{28}$

Images of pre-colonial practitioners of yoga, whether they were philosopher-ascetics engaged in rigorous meditation in pursuit of liberation or sinister villains channeling bodily energy in pursuit of supernatural powers, are hardly the images that we tend to envision when we think of contemporary forms of yoga. Those contemporary forms include the "holistic" yoga prescribed by some contemporary Hindus as well as the postural yoga popularly practiced around the globe.

\section{Modern Yoga}

In popular discourse across much of the world today, yoga is virtually synonymous with postural yoga. But postural yoga is only one thread of modern yoga, which, throughout its history, has itself been characterized by a vast and diverse array of systems.

Largely in response to British colonial and orientalist as well as Indian elite hostility toward hatha yoga for what was deemed a regressive, uncultivated concern with the manipulation of the body, early modern yoga 
reformers sought to reconstruct yoga as a refined Indian spiritual system that was compatible with modern thought. ${ }^{29}$ These attempts resulted in modern yoga.

One such reformer was Swami Vivekananda (1863-1902), a nineteenth-century proselytizing Hindu nationalist known for disseminating yoga to Americans. Both Hindu and Christian opponents of the popularization of yoga point to Vivekananda's teachings as the modern paragon of yoga even though his rendition of yoga was a unique response to the dominant values and concerns of his historical time and place. ${ }^{30}$ Vivekananda reconstructed previously existing yoga systems in light of modern ideas and practices, but he also differed dramatically from future yogis who would eventually construct those popular yoga systems performed on yoga mats across the world today. Vivekananda was influenced by the "harmonial" ideas of emergent European and American metaphysical movements, such as New Thought, which sought a modern, holistic approach aimed at the balance of mind, body, and soul. ${ }^{31}$ Though Hindu opponents of the popularization of yoga trace their vision of authentic yoga, not just to Vivekananda, but also to a pre-colonial ur-system based on a "holistic" practice, holistic care is a modern notion, and its associations with yoga is a modern phenomenon. ${ }^{32}$

Having largely censored yoga of most precolonial yoga body practices and denounced hatha yoga, Vivekananda emphasized meditation and the psychological dimensions of yoga. He constructed a holistic yoga system based on his modern philosophical interpretation of both the Yoga Sutra and Hindu non-dualist thought.

Though hatha yoga is traditionally believed to be the ur-system of modern postural yoga, equating them does not account for the historical sources. Posture only became prominent in modern yoga in the early twentieth century as a result of the dialogical exchanges between Indian reformers and nationalists and Americans and Europeans interested in health and fitness. Postural yoga's historical sources include British military calisthenics, modern medicine, and the physical culture of European gymnasts, body- builders, martial experts, and contortionists. ${ }^{33}$ Inspired by the new ideology underlying physical culture, which deemed the cultivation of the body to be a means of moral reform, early twentieth-century Indian yogis began to emphasize modern renditions of yoga postures, which they associated with hatha yoga, as muscle-building and stretching exercises for the sake of physical fitness. ${ }^{34}$ Though new yoga systems continued to share with pre-colonial yoga an emphasis on training and controlling the mind-body complex, postural yoga repurposed yoga for the sake of modern conceptions of health, beauty, and well-being. ${ }^{35}$

Tirumalai Krishnamacharya (1888-1989), who lived and taught in Mysore, India, and Sivananda Saraswati (1887-1963), who lived and taught in Rishikesh, India, became the first widely influential teachers of postural yoga. ${ }^{36}$ Krishnamacharya's disciples-most significantly, B.K.S. Iyengar, Patabhi Jois, and T.K.V. Desikachar-as well as Sivananda's disciples-most significantly, Vishnudevananda (1927-1993)-went on to mass-market postural yoga in many of the forms that are popular today.

By the late twentieth century, a plurality of yoga brands had emerged, many of which were readily available for consumption in urban areas across the world. ${ }^{37}$ Though popularized varieties are most often forms of postural yoga, they do not all look the same. The most successful yoga brands include: Iyengar Yoga, which emphasizes the use of fitness tools, such as belts, bricks, and ropes; Ashtanga Yoga, which emphasizes the flow from one posture to another in set sequences; and Bikram Yoga, which includes a single sequence of postures in a room heated to one hundred and five degrees Fahrenheit and with forty percent humidity. Despite their differences, all of these aim at modern notions of physical fitness and health and are made up of postural sequences, which are synchronized with the breath. These brands of yoga are not linked explicitly to any particular religious orientation, and their proponents consider them compatible with any religion that accepts a modern biomedical worldview with regard to the body and values health and well-being as defined by that worldview. ${ }^{38}$ 
Other popular postural yoga varieties do explicitly align themselves with particular religious orientations. Anusara Yoga is one example. Inspired by tantra, John Friend created Anusara Yoga in 1997. It is a mix of postural yoga and a life-affirming religiosity based on the idea that "everything in this world is an embodiment of supreme Consciousness, which at its essence pulsates with goodness and the highest bliss." ${ }^{39}$ With over a thousand licensed teachers worldwide, Anusara is one of the most common yoga systems in the global yoga market.

Perhaps more than any other example of postural yoga, Christian Yoga, which emphasizes postures and breath control as means of focusing on Christ, evidences yoga's malleability. Consider Holy Yoga, an "international non-profit ministry," founded by Brooke Boon in 2003. ${ }^{40}$ Since introducing her unique brand of yoga, she has trained hundreds of Holy Yoga instructors who now teach in many areas of the United States and, according to the website, will soon be teaching in Japan, the Philippines, Germany, the United Kingdom, Mexico, India, Afghanistan, and Africa. ${ }^{41}$ Proponents of Christian Yoga argue that yoga itself is not a religion, but a universal set of techniques that can be used to strengthen a Christian's relationship with Christ.

\section{Conclusion}

Contemporary Christian and Hindu opponents of the popularization of yoga are strikingly similar in their attempts to return to what they perceive as the unchanging doctrines and practices of their respective religions, which are perceived to have been intact before modern ideas and their cultural products, including the popularization of postural yoga. Both define yoga as a static, homogenous system in opposition to its popularization.

But the history and development of yoga demonstrate that yoga is anything but homogenous and unchanging. Yoga has a long history whereby adherents of numerous religions, including Hindu, Jain, Buddhist, New Age, and Christian traditions, have deconstructed and reconstructed it anew. Opponents of the popularization of yoga, who build rigid walls around yoga for the sake of arguing that it belongs in the Hindu tradition and accordingly does not belong in others, cannot withstand historical scrutiny, which points to the fact that, when it comes to both meaning and function, yoga is malleable.

\section{Notes}

${ }^{1}$ According to David Gordon White, "Every group in every age has created its own version and vision of yoga. One reason this has been possible is that its semantic field-the range of meanings of the term 'yoga'-is so broad and the concept of yoga so malleable, that it has been possible to morph it into nearly any practice or process one chooses" (David Gordon White, "Introduction," Yoga in Practice, ed. David Gordon White (Princeton: Princeton University Press, 2012), 2). In accordance with White's vision of yoga, Geoffrey Samuel suggests: "[Yoga] has retained some of its integrity as a specific set of techniques for selfcultivation through all of these transformations. To make sense of such a historical complex and varied phenomenon as yoga, it is, however, essential to retain as much awareness as possible of the social environment and historical specificity of each specific context within which it was adopted and transformed. In this way, we can begin to give meaning to each of these various forms of yoga, and to understand them within the life and culture of those who created them and shaped them" (Geoffrey Samuel, "Endpiece," Asian Medicine: Tradition and Modernity 3(1) (2007): 186).

${ }^{2}$ For the history and development of modern postural yoga, see Elizabeth de Michelis, A History of Modern Yoga: Patanjali and Western Esotericism (New York: Continuum, 2004); and Mark Singleton, Yoga Body: The Origins of Modern Posture Practice (New York: Oxford University Press, 2010).

${ }^{3}$ A perusal of recent articles in popular yoga publications, such as Yoga Journal, shows that many contemporary practitioners of yoga colloquially self-identify as yogis. In South Asian yoga traditions, the term was not used until the twelfth- to thirteenth-century Nath Yogi tradition. According to White, "The Nath Yogīs were and remain the sole South Asian order to 
self-identify as yogis" (White, "Introduction," 17).

4 Some contemporary Christians disagree, arguing instead that the benefits of yoga can be separated from the religious dimensions and then reconstructed as a component of the Christian life. One Catholic yogi, Jean Marie Déchanet, prescribed yoga for Christians and coined the term Christian Yoga in her book by that title (Jain Marie Déchanet, Christian Yoga (New York: Harper \& Brothers Publishers, 1960). The Reverend Anthony Randazzo, a Catholic priest at Notre Dame Roman Catholic Church in North Caldwell, N.J., has practiced and taught yoga for over ten years and argues that it has always brought him closer to Christ and that he is "more deeply rooted in the Christian faith than ever" (Alvarez, Lizette, "Bending With a Holy Twist," New York Times, posted November 27, 2010, accessed May 1, 2011, http://cityroom.blogs.nytimes.com/2010/11/2 7/stretching-and-bending-with-a-holytwist/?pagemode=print).

${ }^{5}$ Albert Mohler, "The Subtle Body - Should Christians Practice Yoga?" posted September 20, 2010, accessed September 21, 2010, http://www.albertmohler.com/2010/09/20/th e-subtle-body-should-christians-practiceyoga/.

6 Albert Mohler, "The Meaning of Yoga: A Conversation with Stephanie Syman and Doug Groothuis," Thinking in Public, AlbertMohler.com, posted September 20, 2010, accessed September 21, 2010, http://www.albertmohler.com/2010/09/20/th e-meaning-of-yoga-a-conversation-withstephanie-syman-and-dough-groothius/.

7 Mark Driscoll, "Mark Driscoll on Yoga," YouTube, posted on July 10, 2010, accessed on October 20, 2010, http://www.youtube.com/watch?v=BhcoBLdM $8 \mathrm{CQ}$.

${ }^{8}$ Congregation for the Doctrine of the Faith, "Letter to the Bishops of the Catholic Church," 1989, accessed on May 1, 2011, http://www.ewtn.com/library/CURIA/CDFME D.HTM.

${ }^{9}$ Ibid., 10.

${ }^{10}$ Ibid.
${ }^{11}$ Hindu American Foundation, "Yoga Beyond Asana," posted in 2009, accessed on October 22, 2010,

http://www.hafsite.org/media/pr/yoga-hinduorigins.

${ }^{12}$ Aseem Shukla and Sheetal Shah, "The Rape of Yoga," The Pioneer, June 21, 2011, accessed on July 1, 2011, http://www.dailypioneer.com/252823/Therape-of-Yoga.html.

${ }^{13}$ Ramesh Rao, "It is Wrong to Deny Yoga's Hindu origins," Guardian, posted December 2, 2010, accessed July 1, 2011, http://www.guardian.co.uk/commentisfree/be lief/2010/dec/02/yoga-hindu-rebrandedwrongly/print.

${ }^{14}$ Aseem Shukla, "The Theft of Yoga," Newsweek, posted April 18, 2010, accessed October 26, 2010,

http://newsweek.washingtonpost.com/onfaith /panelists/aseem_shukla/2010/04/nearly_twen ty

_ million_people_in.html. Accessed on October 26, 2010.

${ }^{15}$ Ibid.

${ }^{16}$ Hindu American Foundation, "Yoga Beyond Asana"; Aseem Shukla "The Theft of Yoga." Newsweek, April 18, 2010, accessed on October 26, 2010, http://newsweek.washingtonpost.com/onfaith /panelists/aseem_shukla/2010/04/nearly_twen ty_million_people_in.html.

${ }^{17}$ Ibid.

18 Hindu American Foundation, "Hindu Americans Take Global Stage at Parliament of World Religions," posted on December 13, 2009, accessed on October 24, 2010, http://www.hafsite.org/media/pr/haf-prw.

${ }^{19}$ Shukla, "The Theft of Yoga."

${ }^{20}$ When a New York Times front-page article brought the HAF's campaign widespread attention, Mohler interpreted it as a "vindication" for his own position on yoga (see Paul Vitello "Hindu Group Stirs a Debate Over Yoga's Soul," The New York Times, posted November 27, 2010, accessed November 27, 2010,

http://www.nytimes.com/2010/11/28/nyregio n/28yoga.html; and Albert Mohler, "Help from Hindu Quarters - The New York Times on 'Take Back Yoga," AlbertMohler.com Blog, posted on 
November 29, 2010, accessed November 30, 2010, http://www.albertmohler.com/2010/11/29/hel p-from-hindu-quarters-the-new-york-timeson-take-back-yoga/).

${ }^{21}$ Geoffrey Samuel, Origins of Yoga and Tantra: Indic Religions to the Thirteenth Century (Cambridge: Cambridge University Press, 2008), 2.

${ }^{22}$ White, "Introduction," 3.

${ }^{23}$ Samuel, "Endpiece," 179.

${ }^{24}$ On interreligious exchange in the history of yoga, see Louis De la Vallée Poussin, "Le Bouddhisme et le yoga de Patañjali," Mélanges Chinois et Bouddhiques 5 (1936-1937): 223-242; G. J. Larson, "An Old Problem Revisited: The Relation between Sāmkhya, Yoga and Buddhism," Studien zur Indologie und Iranistik 15 (1989): 129-146; J. Bronkhorst, The Two Traditions of Meditation in Ancient India, (Delhi: Motilal Banarsidass, 1993); J. Bronkhorst, The Two Sources of Indian Asceticism, second edition (Delhi: Motilal Banarsidass, 1998); Olle Qvarnström, "Losing One's Mind and Becoming Enlightened," Yoga, The Indian Tradition, ed. Ian Whicher and David Carpenter (London: Routledge Curzon, 2003), 131-133; and Samuel, Origins of Yoga and Tantra.

${ }^{25}$ White, "Introduction," 12.

${ }^{26}$ David Gordon White, The Alchemical Body: Siddha Traditions in Medieval India (Chicago: University of Chicago Press, 1996); David Gordon White, Sinister Yogis (Chicago: University of Chicago Press, 2009).

${ }^{27}$ White, "Introduction," 17-18.

${ }^{28}$ For a detailed account of this yogi tradition, see White, Sinister Yogis.

${ }^{29}$ See Singleton, Yoga Body.

${ }^{30}$ See Albert Mohler, "The Meaning of Yoga"; Hindu American Foundation, "Yoga Beyond Asana."

31 On the influence of New Thought on Vivekananda, see de Michelis, A History of Modern Yoga, 168.

${ }^{32}$ On modern conceptions of the "holistic" development of the individual, including those found in modern gymnastic systems and "harmonial" religious systems, such as New Thought, and their influence on modern yoga, see Singleton, Yoga Body, 81-162.
${ }^{33}$ N. E. Sjoman, The Yoga Tradition of the Mysore Palace (New Delhi: Abhinav Publications, 1996); Joseph S. Alter, Yoga in Modern India: The Body between Science and Philosophy, Princeton: Princeton University Press, 2004; Singleton, Yoga Body.

${ }^{34}$ Singleton, Yoga Body.

${ }^{35}$ De Michelis, A History of Modern Yoga; Suzanne Newcombe, "Stretching for Health and WellBeing: Yoga and Women in Britain, 1960-1980" Asian Medicine: Tradition and Modernity 3(1) (2007): 37-63; Singleton, Yoga Body.

${ }^{36}$ Sarah Strauss, Positioning Yoga: Balancing Acts Across Cultures (New York: Berg, 2005); Singleton, Yoga Body.

${ }^{37}$ See Andrea R. Jain, "Branding Yoga: The Cases of Iyengar Yoga, Siddha Yoga, and Anusara Yoga," Approaching Religion, forthcoming.

38 Iyengar Yoga has affiliated its form of postural yoga with the yoga tradition presented in the Yoga Sutra, usually attributed to Patanjali, by introducing an invocation to Patanjali at the beginning of each yoga class. Iyengar, however, insists that yoga, though a part of an ancient South Asian yoga lineage, is not specific to any religious tradition (On the invocation to Patanjali in Iyengar Yoga, see Joy Laine, "Contemporary Yoga and its Contested Domains," paper presented at the annual meeting for the American Academy of Religion, San Francisco, California, November 19-22, 2011).

39 Anusara Yoga, "Philosophy," posted 2009, accessed March 1, 2012, http://www.anusara.com/index.php?option=co m_content\&view=article\&id=51\&Itemid=85.

40 "About Holy Yoga," accessed March 25, 2012, https://holyyogafoundation.com/about/3/. ${ }^{41}$ Ibid. 